Washington

LEGISLATION committing hundreds of millions of dollars to new programmes designed to improve the knowledge of school mathematics and science teachers may have little impact on the declining performance of US schoolchildren. That is the unexpected conclusion of a heretical study just published by the congressional General Accounting Office (GAO). The study, which contradicts the recommendations of almost all the recent reports on the plight of US high schools, has provoked sharp criticism from the National Science Foundation (NSF), the Department of Education and the White House Office of Science and Technology Policy (OSTP).

Dr James Ling, assistant director of OSTP, has written to GAO complaining that the report is clearly biased against upgrading the quality of existing mathematics and science teachers and that it "suppresses" evidence that teacher retraining programmes have indeed improved the performance of students. Dr Edward Knapp, director of NSF, says the report is "unfortunate and counterproductive"'. The Department of Education says it disagrees with most of the report's major conclusions.

This angry reception can be traced in part to unfortunate timing. Concern about the poor state of mathematics and science education in the United States - reflected by a 20-year decline in scores on the Scholastic Aptitude Test - reached a peak last year. A national commission on education set up by the Reagan Administration said standards had declined so much that the nation was "at risk". And a comprehensive report by the National Science Board called for a $\$ 1,000$ million a year programme to retrain mathematic and science teachers and establish 2,000 "model" schools where innovative approaches to mathematics and science teaching could be encouraged.

These and other reports have stimulated a wave of educational reforms at state level. But there is precious little to show for them nationally except for two bills which, supporters glumly concede, stand little chance of becoming law before the presidential election at the end of the year. In March 1983, the House of Representatives approved an Emergency Mathematics and Science Education and Jobs Act. In the Senate, an Education for Economic Security Act was reported out of committee last May. Both bills would pump an additional $\$ 400$ million a year (enough to spend nearly $\$ 2,000$ on every secondary mathematics and science teacher) into mathematics and science education.

Neither bill has been able to generate enough support to move much further. What support they do have could be seriously damaged if the GAO report is given wide credence. Central to both bills are proposals for teachers' institutes and other forms of in-service training designed to refresh the knowledge of teachers already employed to specialize in mathematics and science. Yet the GAO study, after reviewing attempts to do the same thing in the past, says there is a good chance that such measures will have no effect on the performance of the schools.

The report takes as its starting point the summer institutes organized by NSF between the mid-1950s and the mid-1970s. Participation was widespread. A 1971 survey found that 51 per cent of secondary science teachers had attended one or more institutes, established to "increase the effectiveness of teachers by broadening and updating their scientific background". The scheme ended in 1975 when the shortage of scientists became a surplus and NSF's curriculum development programmes ran into political hot water over a controversial social science course. But how effective, meanwhile, had the institutes been?

According to GAO, only one useful research project ever asked that question and its results were ambivalent. Highschool students of teachers who had attended the institutes did better but junior high-school students did not. So GAO tried to answer the question a different way.

Mathematical and scientific knowledge, not teaching skills, dominated the institute courses. Do teachers who know more about their subject actually get better results from their students? The intriguing evidence from recent research is that they do not.

This finding, GAO argues, has important implications for public policy. Spending heavily to improve the knowledge of existing mathematics and science teachers, for example, may not be as effective as converting good teachers from other subject areas. And it may be better to concentrate, in retraining courses, on general pedagogic skills than on substantive knowledge of a discipline.

Both conclusions run counter to conventional wisdom. Its critics say the GAO report jumps to conclusions that cannot be supported by the slender research findings it reviews. Even so, the report is a disturbing warning that the problems of quality, if not quantity, of mathematics and science teaching may not be as tractable as supporters of expensive legislation believe.

In Illinois, for example, five laboratories belonging to the Illinois Research Corridor have banded together to offer summer jobs to superior science and mathematics teachers from their local schools. The five - Amoco Research Center, Argonne, Bell Labs, the Nalco Chemical Company and Fermilab - say the programme was designed to be interesting and relevant but contains no formal attempt to improve specific teaching skills.

Both the teachers and the laboratories which hired them claim, on the basis of the first summer, that the scheme has been outstandingly successful. More laboratories intend to participate this year. The teachers, now back in their schools, report renewed interest in teaching and increased confidence in their own abilities.

Peter David

\title{
Bug takes to the ski slopes
}

IT seems that Pseudomonas syringae, the obscure Gram-negative bacterium that was recently catapulted to world fame when plans to conduct field trials with a genetically engineered version were blocked in the United States, may yet play a larger part in the affairs of men. Last October, plans for a field trial that entailed the release of genetically engineered $\boldsymbol{P}$. syringae lacking the bacterium's ice nucleation protein had to be postponed after objections from environmental groups. But researchers at Advanced Genetic Sciences Inc, at Oakland, California, hope to use other organisms expressing the same protein to gain a lead in the lucrative market for artificial snow used on ski slopes.

The use of nucleatormakessnow-making much easier than it would otherwise be, as it largely prevents the water from becoming super-cooled. Water is simply sprayed through a fine nozzle onto a fan, and the expansion-induced cooling produces snow. But there are problems with existing nucleation agents, and the $P$. syringae protein fits the bill perfectly.

Dr Trevor Suslow, who is working on the project, says the company is ready to scale up to full production with a system using whole freeze-dried $P$. syringae. Although the bacterium is harmless, it will be killed - probably by gamma irradiation before use, if only to reassure skiers who lack a knowledge of basic bacteriology.

With this system, ice forms at about $-3^{\circ} \mathrm{C}$. But when the regulatory hurdles standing in the way of releasing genetically engineered organisms are overcome, the company hopes to use other bacteria to produce the protein. An even more efficient and inexpensive ice nucleator may then become possible.

Tim Beardsley 